To Maega | Jurnal Pengabdian Masyarakat

Februari 2022, Vol.5, No.1, hal, 75-83

$\operatorname{ISSN}(P): 2622-6332 ; \operatorname{ISSN}(E): 2622-6340$

http://www.ojs.unanda.ac.id/index.php/tomaega

\title{
Penyuluhan Penggunaan Oralit Pada Diare Anak dan Demo Cuci Tangan yang Baik dan Benar
}

\author{
Reza Rahmawati ${ }^{*}$, Yona Harianti Putri ${ }^{1}$, Jihan Su'da R. ${ }^{1}$, Aanisah Hanuun ${ }^{1}$, \\ Tesa Pebiani ${ }^{1}$ \\ ${ }^{1}$ Program Studi Farmasi, Fakultas Matematika dan IImu Pengetahuan Alam, Universitas \\ Bengkulu
}

*Correspondent Email: rezarahmawati@unib.ac.id

\section{Article History:}

Received: 14-11-2021; Received in Revised: 16-12-2021; Accepted: 21-12-2021

DOI: http://dx.doi.org/10.35914/tomaega.v5i1.956

\begin{abstract}
Abstrak
Penyakit diare merupakan salah satu penyebab kematian pada bayi dan anak-anak. Salah satu penyebab kematian akibat diare karena komplikasi dehidrasi. Oralit merupakan salah satu terapi yang dapat mencegah terjadinya dehidrasi dan mengganti cairan tubuh yang hilang. Kebiasaan mencuci tangan dan menjaga kebersihan dapat mencegah kejadian penyakit diare. Oleh karena itu, kegiatan pengabdian kepada masyarakat ini bertujuan untuk meningkatkan penggunaan oralit sebagai salah satu terapi diare pada anak dan edukasi mengenai langkah mencuci tangan yang baik dan benar sebagai upaya pencegahan penyakit diare. Metode yang dilakukan ialah metode ceramah dengan pemberian materi dan leaflet, melakukan demo mencuci tangan yang baik dan benar, serta diskusi yang dilakukan kepada Ibu-Ibu warga RT 023 RW 001 Kelurahan Dusun Besar Kota Bengkulu. Hasil dari kegiatan penyuluhan ini didapatkan kenaikan pengetahuan peserta sebelum dan sesudah dilakukan kegiatan penyuluhan yaitu sebesar 32,47\% mengenai diare, penggunaan oralit dan langkah mencuci tangan. Selain itu, dilakukan pula pemberian donasi 50 buah sabun cuci tangan dan 2 buah poster langkah mencuci tangan kepada perwakilan RT setempat.
\end{abstract}

Kata Kunci: Diare, Oralit, Cuci Tangan, Anak, Penyuluhan

\begin{abstract}
Diarrhea is one of disease cause of death in pediatric. The main cause of death due to complication of dehydration. Oral Rehydration Solution (ORS) is a therapy that can prevent dehydration and replace lost body fluids. Washing hands behaviour and maintaining cleanliness can prevent the incidence of diarrhea diseases. Therefore, this community service activity aims to increase the use of ORS as a therapy for diarrhea in children and practice proper steps of washing hands as an effort to prevent diarrheal disease. The method of this activity by counseling with providing materials and leaflets to the participants. The results showed an increase in participants' knowledge before and after the counseling process, which was $32.47 \%$. In addition, donations of 50 hand soaps and 2 handwashing posters were also made to local RT representatives.
\end{abstract}

Key Word: Diarrhea, Oralit, Hand Washing, Pediatric, Counseling. 

2022

\section{Pendahuluan}

Penyakit diare merupakan salah satu permasalahan dalam kesehatan anak. Menurut World Health Organization (WHO), diare merupakan penyebab kedua kematian pada anak di bawah usia 5 tahun yaitu sekitar 760.000 kasus/tahun (CaJacob dan Cohen, 2016). Di Indonesia, diare diderita oleh semua kelompok usia dengan kasus paling banyak terjadi pada anak di bawah usia 5 tahun yaitu sekitar 16,7\%. Diare juga menjadi penyebab kematian pada bayi yaitu sekitar 31,4\% (Rendang Indriyani \& Putra, 2020). Menurut laporan Riskesdas tahun 2018, prevalensi diare di provinsi Bengkulu adalah 17.419 kasus dan sebanyak 1.572 kasus adalah balita berusia 0-59 bulan (Tim Riskesdas, 2019).

Diare adalah proses buang air besar sebanyak 3 kali atau lebih dengan konsistensi tinja/feses berbentuk cair atau frekuensi lebih dari normal (Juffrie dkk., 2010). Diare dapat disebabkan oleh infeksi virus, bakteri, dan parasit. Sekitar $40 \%$ kasus diare yang terjadi pada bayi sampai usia 5 tahun disebabkan oleh rotavirus dan 30\% kasus disebabkan oleh norovirus dan adenovirus. 20\% kasus lainnya disebabkan oleh bakteri dan parasit kurang dari 5\% (Koletzko dan Osterrieder, 2009). Manifestasi klinik dari diare adalah muntah, demam, dan feses berbentuk cair (Imanadhia dkk., 2019). Salah satu penyebab kematian akibat diare pada anak adalah dehidrasi akibat komplikasi diare. Dehidrasi merupakan salah satu indikator penentuan keparahan penyakit diare (CaJacob dan Cohen, 2016).

Terapi untuk mengatasi penyakit diare dapat dilakukan dengan rehidrasi, pemberian supplemen zink, pemberian nutrisi yang adekuat, penggunaan antibiotik selektif, dan pemberian edukasi kepada orang tua/pengasuh (Imanadhia dkk., 2019). Tujuan utama pengobatan diare adalah dengan menggantikan cairan dan elektrolit tubuh yang hilang akibat dari diare dan muntah (Koletzko dan Osterrieder, 2009) Rehidrasi dapat dilakukan dengan pemberian oralit pada masa awal terjadinya diare. Oralit merupakan campuran garam elektrolit, seperti natrium klorida $(\mathrm{NaCl})$, kalium klorida $(\mathrm{KCl})$, dan trisodium sitrat hidrat, serta glukosa anhidrat yang dapat diberikan secara oral untuk menggantikan cairan tubuh yang hilang. Penelitian melaporkan bahwa pemberian oralit dapat mengatasi dehidrasi ringan dan sedang pada diare akut (Radlovic dkk., 2015).

Kasus kematian akibat diare semakin menurun. Hal ini disebabkan karena kebiasaan menjaga kebersihan dan penggunaan oralit dapat menurunkan angka kematian akibat dehidrasi yang disebabkan oleh diare (Drancourt, 2017). Berdasarkan laporan Riskesdas tahun 2018, penggunaan oralit pada diare balita di provinsi Bengkulu adalah 36,74\%. Sehingga untuk meningkatkan penggunaan oralit pada diare anak, maka perlu dilakukan edukasi kepada masyarakat terkait oralit dan cara penggunaanya sebagai upaya mengatasi dehidrasi yang terjadi akibat diare (Tim Riskesdas, 2019).

Salah satu upaya dalam mengendalikan penularan diare ialah dengan menjga kebersihan. Penelitian yang dilakukan di India melaporkan bahwa kebiasaan mencuci tangan dengan sabun mampu menurunkan angka kejadian diare 
hingga 53\% (Drancourt, 2017). Penelitian lain melaporkan bahwa kebiasaan mencuci tangan dengan sabun dapat menurunkan kejadian diare sebesar $47 \%$. Individu yang tidak memiliki kebiasaan mencuci tangan yang baik dapat meningkatkan resiko terjadinya diare hingga 7 kali dibanding dengan individu memiliki kebiasaan mencuci tangan. Sekitar 83,1\% masyarakat belum memiliki pengetahuan yang baik mengenai mencucui tangan (Amelia, 2018). Oleh karena itu perlu dilakukan penyuluhan dan demo mengenai langkah mencuci tangan yang baik dan benar kepada masyarakat sebagai upaya pencegahan penyakit diare terutama pada anak.

\section{Metode}

Kegiatan pengabdian kepada masyarakat ini dilakukan di RT 023 RW 001 Kelurahan Dusun Besar Kota Bengkulu. Sasaran dari kegiatan ini ialah Ibu-Ibu warga setempat dan juga tokoh masyarakat dimana dalam kegiatan ini tokoh masyarakat yang dimaksud adalah Ibu RT setempat. Kegiatan ini dilakukan pada hari Minggu tanggal 12 September 2021 dan diikuti oleh 20 orang peserta.

Metode yang dilakukan untuk mencapai tujuan yang diharapkan dalam kegiatan pengabdian masyarakat ini dalam proses pemberian pendidikan atau edukasi kepada masyarakat setempat mengenai diare anak, penggunaan oralit dan langkah mencuci tangan ialah melalui penyuluhan dan juga mempraktekkan demo cuci tangan yang baik dan benar sebagai salah satu upaya pencegahan penyakit diare. Proses pelaksanaan penyuluhan dilakukan dengan metode ceramah dan dilanjutkan dengan sesi diskusi tanya jawab. Dalam metode penyuluhan, peserta diberikan cetakan materi penyuluhan dan juga leaflet sebagai salah satu sarana edukasi.

Materi penyuluhan dan leaflet berisi tentang penjelasan mengenai diare, tata laksana terapi diare, pengertian oralit, manfaat dan cara penggunaan oralit, serta langkah mencuci tangan yang baik dan benar. Dalam kegiatan ini juga dilaksanakan pretest dan juga posttest sebelum dan sesudah proses penyuluhan untuk menilai apakah terdapat peningkatan pengetahuan yang diperoleh oleh masyarakat dalam pelaksanaan kegiatan pengabdian kepada masyarakat ini.

Tahapan yang dilaksanakan dalam kegiatan pengabdian kepada masyarakat ini adalah:

a. Tahapan persiapan

Adapun kegiatan yang dilakukan pada tahap ini antara lain:

1) Pengurusan perizinan kepada RT setempat terkait dengan pelaksanaan acara pengabdian.

2) Diskusi terkait jadwal, waktu dan tempat pelaksanaan pengabdian dengan Ibu RT setempat.

3) Pembuatan dan penyiapan alat dan bahan penyuluhan terkait penyuluhan penggunaan oralit pada diare anak dan cara mencuci tangan, seperti pembuatan materi penyuluhan, leaflet/brosur, poster cara mencuci tangan, serta 
[ 78 ] Reza Rahmawati, dkk/To Maega: Jurnal Pengabdian Masyarakat, Vol.5; No.1; Februari, 2022

mempersiapkan alat-alat yang dibutuhkan seperti handsanitizer, sabun cuci tangan, dan oralit.

b. Tahapan pelaksanaan

Tahapan pelaksanaan kegiatan dilakukan dengan memberikan penyuluhan mengenai penjelasan terkait diare, tata laksana terapi diare, pengertian oralit, manfaat dan cara penggunaan oralit, serta langkah mencuci tangan yang baik dan benar serta melakukan demo cuci tangan kemudian dilanjutkan dengan diskusi tanya jawab. Selain itu dilakukan juga pretest dan posttest yang dilakukan sebelum dan sesudah pemberian penyuluhan untuk menilai apakah terdapat peningkatan pengetahuan yang diperoleh oleh masyarakat dalam pelaksanaan kegiatan pengabdian kepada masyarakat ini.

c. Tahapan evaluasi

Tahapan evaluasi dilakukan dengan cara menganalisis hasil pretest dan posttest yang dilakukan kepada peserta untuk mengetahui apakah terdapat peningkatan pengetahuan setelah dilakukan kegiatan penyuluhan kepada peserta.

\section{Hasil dan Pembahasan}

Kegiatan penyuluhan dilakukan pada hari Minggu tanggal 12 September 2021 berjalan lancar dan baik. Proses awal kegiatan diawali dengan tahap perijinan kepada ketua RT setempat dan dilanjutkan dengan penentuan waktu dan tempat kegiatan. Setelah itu dilanjutkan dengan mempersiapkan alat dan bahan yang dibutuhkan untuk kegiatan pengabdian masyarakat ini. Alat dan bahan yang dipersiapkan antara lain materi penyuluhan, leaflet/brosur, poster cara mencuci tangan, serta mempersiapkan alat-alat yang dibutuhkan seperti handsanitizer, sabun cuci tangan, dan oralit.

Tahap pelaksanaan diawali dengan proses pemberian penyuluhan dengan metode ceramah kemudian dilanjutkan dengan sesi diskusi. Proses pemberian penyuluhan kepada warga setempat dilakukan dengan penyampaian materi dan juga pemberian cetakan materi serta leaflet sebagai salah satu media pemberian edukasi. Penelitian menunjukkan bahwa pemberian edukasi melalui media leaflet dapat meningkatkan pengetahuan (Herman dkk., 2020).

Kegiatan awal diawali dengan pemberian pretest terlebih dahulu untuk menilai pemahaman dan pengetahuan masyarakat mengenai diare, penggunaan oralit, dan langkah mencuci tangan. Setelah itu kegiatan dilanjutkan dengan pemberian penyuluhan mengenai diare yang meliputi pengertian diare, penyebab diare, gejala diare, tata laksana diare serta penggunaan oralit dan manfaat pemberian oralit dalam mengatasi diare. Oralit merupakan salah satu terapi yang dapat dilakukan untuk mencegah komplikasi dehidrasi pada diare anak (Radlovic dkk., 2015). Oralit yang diberikan pada awal saat terjadi diare pada anak di rumah 
dapat menurunkan durasi, keparahan, rawat inap, biaya pengobatan, dan kematian pada anak dibawah usia 5 tahun (Abbas dkk., 2018). Dengan adanya pemberian edukasi mengenai penggunaan oralit dan manfaat pemberian oralit, diharapkan dapat meningkatkan penggunaan oralit sebagai terapi awal terjadinya diare pada anak di rumah sehingga mencegah terjadinya dehidrasi yang dapat menyebabkan kematian pada anak. Adapun pelaksanaan kegiatan penyuluhan dapat dilihat pada gambar 1.

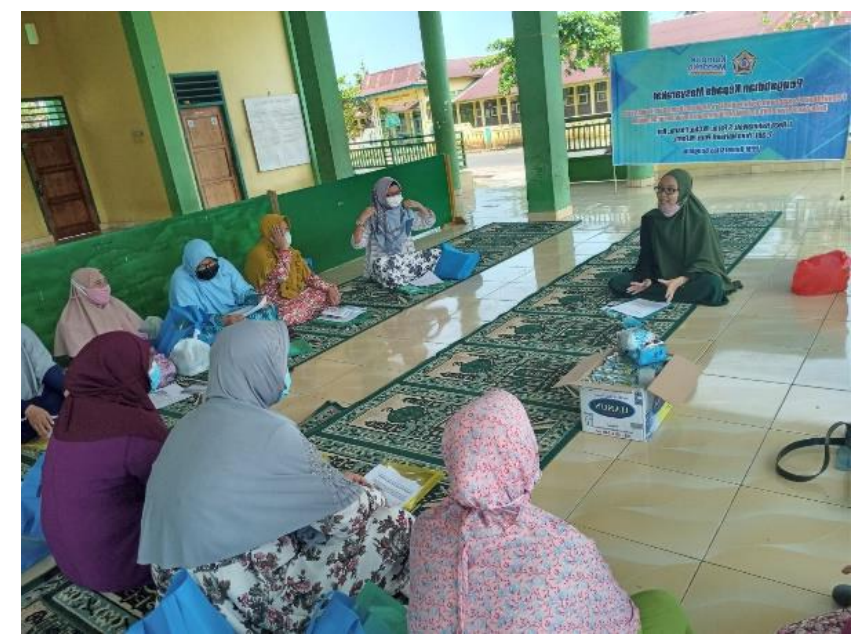

Gambar 1. Pemberian Penyuluhan mengenai Diare dan Oralit

Kegiatan selanjutnya dilakukan penyuluhan mengenai langkah mencuci tangan yang baik dan benar disertai dengan dilakukannya demo cuci tangan bersama para peserta penyuluhan. Hasil penelitian menunjukkan bahwa kebiasaan mencuci tangan memiliki pengaruh yang signifikan terhadap kejadian diare. Dengan mencuci tangan yang baik dan benar dapat mencegah penularan diare (Ruhyanuddin, 2017). Penelitian melaporkan bahwa penggunaan oralit dan prilaku hidup bersih dapat menurunkan kematian akibat diare di negara berkembang (Salam dkk., 2012). Penelitian yang dilakukan di India melaporkan bahwa kebiasaan mencuci tangan dengan sabun mampu menurunkan angka kejadian diare hingga 53\% (Drancourt, 2017). Sehingga diharapkan dengan pengetahuan dan pemahaman mengenai cara mencuci tangan yang baik dan benar, masyarakat dapat menerapkan hal tersebut dalam kehidupan sehari-hari sehingga dapat menurunkan kejadian diare terutama pada anak. Adapun pelaksanaan kegiatan demo cuci tangan dapat dilihat pada gambar 2 . 


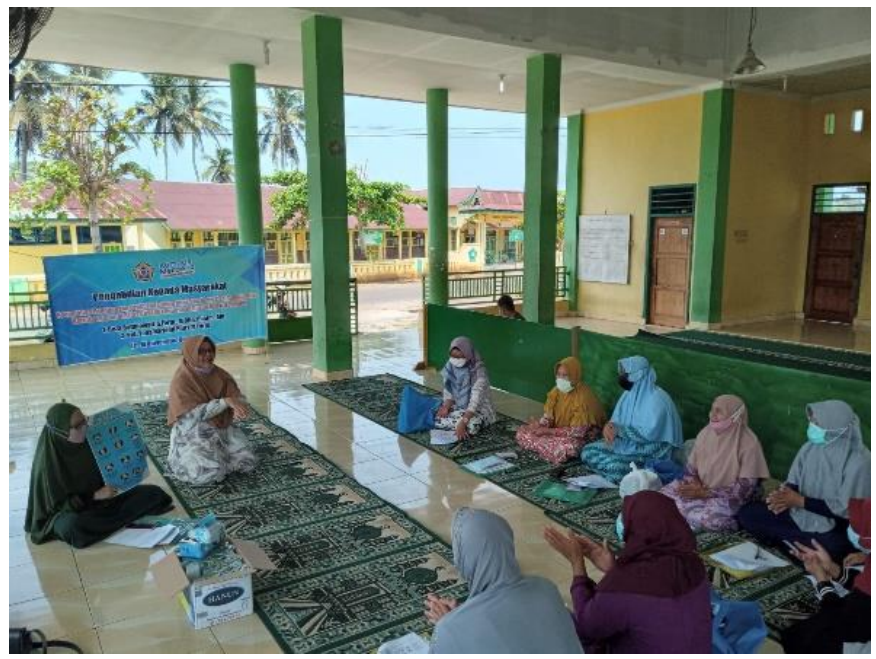

Gambar 2. Demo Cuci Tangan yang Baik dan Benar

Sebelum dan sesudah pelaksanaan penyuluhan dan demo cuci tangan, para peserta yang hadir diberikan pretest dan posttest untuk mengetahui pengetahuan dan pemahaman mereka terkait materi yang akan disampaikan serta untuk mengukur apakah terdapat peningkatan pengetahuan dan pemahaman setelah diberikan penyuluhan. Pretest dan posttest berisi 7 pertanyaan terkait pengetahuan peserta mengenai diare, oralit, serta cara mencuci tangan. Hasil dari nilai tersebut dapat terlihat pada tabel 1 berikut. Dari hasil pretest dan posttest yang dilakukan, terlihat terdapat peningkatan pengetahuan yang didapatkan oleh peserta penyuluhan sebesar $32.47 \%$.

Tabel 1. Hasil Pretest dan Posttest dalam Pelaksanaan Penyuluhan

\begin{tabular}{|c|l|c|c|c|}
\hline No. & \multicolumn{1}{|c|}{ Pertanyaan } & $\begin{array}{c}\text { Pretest } \\
(\mathbf{\%})\end{array}$ & $\begin{array}{c}\text { Posttest } \\
(\mathbf{\%})\end{array}$ & $\begin{array}{c}\text { Peningkatan } \\
(\mathbf{\%})\end{array}$ \\
\hline 1 & Definisi diare & 60.61 & 87.88 & 27.27 \\
\hline 2 & Tatalaksana/pengobatan diare & 36.36 & 87.88 & 51.52 \\
\hline 3 & Pemberian oralit saat diare & 57.58 & 87.88 & 30.30 \\
\hline 4 & Cara pembuatan larutan oralit & 48.48 & 84.85 & 36.36 \\
\hline 5 & Manfaat pemberian oralit & 60.61 & 87.88 & 27.27 \\
\hline 6 & $\begin{array}{l}\text { Mencuci tangan untuk mencegah } \\
\text { diare }\end{array}$ & 72.73 & 90.91 & 18.18 \\
\hline 7 & Langkah mencuci tangan & 48.48 & 84.85 & 36.36 \\
\hline & Rata-rata & 54.98 & 87.45 & 32.47 \\
\hline
\end{tabular}




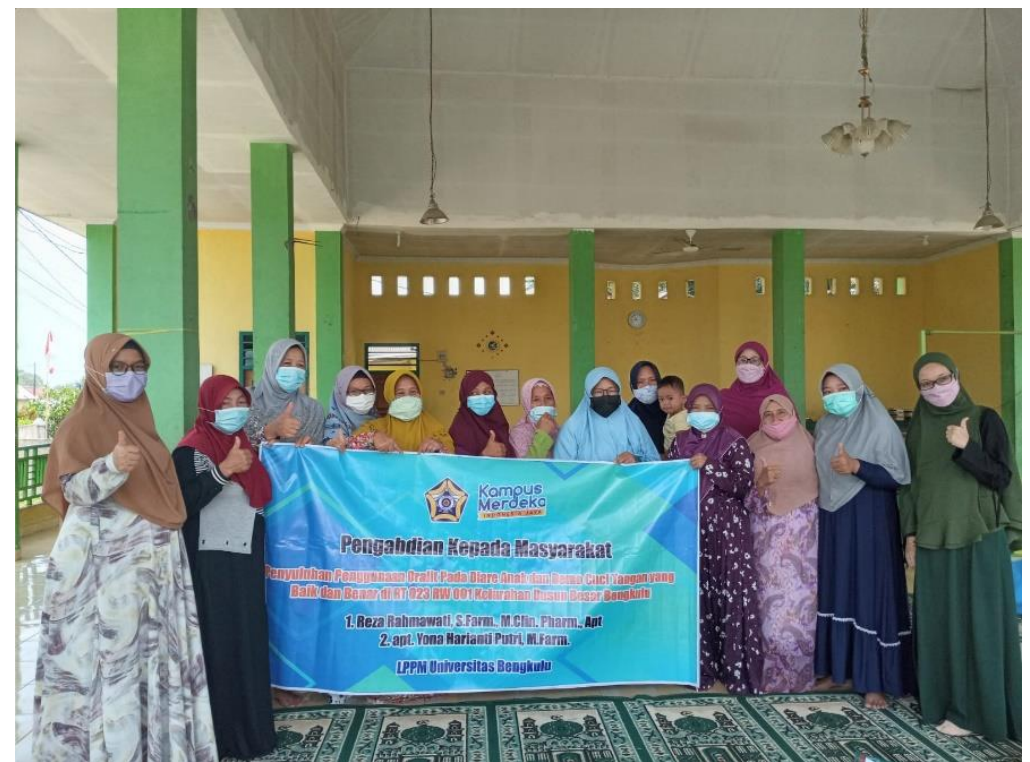

Gambar 3. Kegiatan Pengabdian Kepada Masyarakat

Dalam kegiatan pengabdian kepada masyarakat ini juga dilakukan pemberian donasi 50 buah sabun cuci tangan yang akan dibagikan kepada warga setempat dan poster mengenai langkah mencuci tangan yang baik dan benar. Media poster dapat memberikan peningkatan pengetahuan (Linasari, 2017). Harapannya semakin banyak warga yang teredukasi melalui media poster dan meningkatkan kesadaran warga untuk meningkatkan kebiasaan mencuci tangan yang baik dan benar sehingga terhindar dari berbagai penyakit yang menular melalui tangan terutama diare.

\section{Kesimpulan}

Kegiatan pengabdian kepada masyarakat mengenai penggunaan oralit pada diare anak dan demo cuci tangan yang baik dan benar melalui metode penyuluhan ini memberikan peningkatan pengetahuan dan pemahaman kepada Ibu-Ibu warga RT 023 RW 001 Dusun Besar Bengkulu sebesar 32,47\%. Dalam kegiatan ini juga dilakukan pembagian oralit dengan tujuan untuk meningkatkan penggunaan oralit pada diare anak dan juga pembagian sabun cuci tangan sebagai salah satu upaya untuk menjaga kebersihan tangan dan pencegahan penyakit diare.

\section{Ucapan Terimakasih (Optional)}

Terima kasih kepada Lembaga Penelitian dan Pengabdian Kepada Masyarakat (LPPM) Universitas Bengkulu yang telah mendanai kegiatan ini dengan nomor kontrak: 2030/UN30.15/AM/2021 serta terima kasih kepada warga masyarakat RT 023 RW 001 Dusun Besar Bengkulu atas partisipasinya dalam kegiatan Pengabdian Kepada Masyarakat. 
[ 82] Reza Rahmawati, dkk/To Maega : Jurnal Pengabdian Masyarakat, Vol.5; No.1; Februari, 2022

\section{Daftar Pustaka}

Abbas, J., Chandra Pandey, D., Verma, A., and Kumar, V. (2018). Management of acute diarrhea in children: Is the treatment guidelines is really implemented? International Journal of Research in Medical Sciences, 6(2), 539. https://doi.org/10.18203/2320-6012.ijrms20180294

Amelia, R. (2018). The Relationship Between Basic Sanitation and Personal Hygiene with The Incidence of Diarrhea In Medan City. Proceedings of the 2nd Public Health International Conference (PHICo 2017). 2nd Public Health International Conference (PHICo 2017), Medan, Indonesia. https://doi.org/10.2991/phico-17.2018.37

CaJacob, N. J., and Cohen, M. B. (2016). Update on Diarrhea. Pediatrics in Review, 37(8), 313-322. https://doi.org/10.1542/pir.2015-0099

Drancourt, M. (2017). Acute Diarrhea. Infectious Diseases, 335-340. https://doi.org/doi:10.1016/B978-0-7020-6285-8.00038-1

Herman, H., Citrakesumasari, C., Hidayanti, H., Jafar, N., dan Virani, D. (2020). Pengaruh Edukasi Gizi Menggunakan Leaflet Kemenkes Terhadap Perilaku Konsumsi Sayur Dan Buah Pada Remaja Di Sma Negeri 10 Makassar. Jurnal Gizi Masyarakat Indonesia: The Journal of Indonesian Community Nutrition, 9(1). https://doi.org/10.30597/jgmi.v9i1.10157

Imanadhia, A., Ranuh, I. R. G., dan Nuswantoro, D. (2019). Etiology Based on Clinical Manifestation of Acute Diarrhea Incidence of Children Hospitalized in Dr. Soetomo General Hospital Surabaya Period 2011-2013. Biomolecular and Health Science Journal, 2(1), 31. https://doi.org/10.20473/bhsj.v2i1.12744

Juffrie, M., Soenarto, S., dan Oswar, H. (2010). Buku Ajar GastroenterologiHepatologi. Ikatan Dokter Anak Indonesia.

Koletzko, S., dan Osterrieder, S. (2009). Acute Infectious Diarrhea in Children. Deutsches Ärzteblatt International, 12.

Linasari, L. (2017). Pengaruh Penggunaan Media Poster Dan Leaflet Terhadap Pengetahuan Siswa Sma Di Bandar Lampung Tentang Karies Gigi. Jurnal Keperawatan, 13, 103-109.

Radlovic, N., Lekovic, Z., Vuletic, B., Radlovic, V., and Simic, D. (2015). Acute diarrhea in children. Srpski Arhiv Za Celokupno Lekarstvo, 143(11-12), 755762. https://doi.org/10.2298/SARH1512755R

Rendang Indriyani, D. P., dan Putra, I. G. N. S. (2020). Penanganan terkini diare pada anak: Tinjauan pustaka. Intisari Sains Medis, 11(2), 928. https://doi.org/10.15562/ism.v11i2.848

Ruhyanuddin, F. (2017). Perilaku Mencuci Tangan Berdampak Pada Insiden Diare Pada Anak Usia Sekolah Di Kabupaten Malang. 8, 11. 
[83] Reza Rahmawati, dkk / To Maega : Jurnal Pengabdian Masyarakat, Vol.5; No.1; Februari, 2022

Salam, M., Lindberg, G., Dite, P., Khalif, I., Salazar-Lindo, E., Ramakrishna, B. S., Goh, K., Thomson, A., Khan, A. G., Krabshuis, D. J., \& LeMair, D. A. (2012). Prof. M. Farthing (Chair, United Kingdom). 24.

Tim Riskesdas 2018. (2019). Laporan Provinsi Bengkulu Riskesdas 2018. Lembaga Penerbit Badan Penelitian dan Pengembangan Penelitian. 